\title{
IMPLEMENTASI PROGRAM EPPM-UKM UNTUK PENGUATAN KINERJA MANAJEMEN UKM DAN INDUSTRI KREATIF
}

\author{
Wahyudiono \\ wahyudiono@narotama.ac.id \\ R. Agus Baktiono \\ Universitas Narotama Surabaya
}

\begin{abstract}
This study aims to examine the effect of the ePPM-SMEs implementation to the value of management capability and management performance. Furthermore, this study examines the effect of management capability towards management performance as well. This study is an explanative or associative study which is used hypothesis testing. The study was conducted in groups of SMEs or creative industries spread over five cities or regions in East Java. The population is determined by the criteria of SMEs or creative industry which participate in the ePPM-SMEs program as owner and being active in business for at least five years. Based on these criteria, there are 60 SMEs or creative industries who meet the criteria. Since all members of the population are members of the sample as well so this study is also called as complete enumeration method. The results of path analysis show that the ePPM-SMEs program directly and significantly affects the management capability and management performances as well as management capability towards management performances. The results of this study indicate that the structured implementation of ePPM-SMEs program produced more creative and innovative of management capability. In addition, innovative management capabilities will result to the more effective and efficient management performance.
\end{abstract}

Key words: ePPM-SMEs; capability; performance; management; web

\begin{abstract}
ABSTRAK
Penelitian ini bertujuan menguji pengaruh implementasi ePPM-UKM terhadap nilai kemampuan manajemen dan kinerja manajemen serta menguji pengaruh kemampuan manajemen terhadap nilai kinerja manajemen. Penelitian ini termasuk jenis penelitian ekplanatif atau asosiatif yang disertai dengan pengujian hipotesis. Penelitian dilakukan pada kelompok UKM atau industri kreatif yang tersebar pada lima wilayah kota atau kabupaten di Jawa Timur. Populasi ditentukan melalui kriteri pernah mengikuti program ePPM-UKM, sebagai pemilik UKM, aktif berusaha minimal lima tahun. Berdasarkan kriteria tersebut terdapat 60 pelaku UKM atau industri kreatif yang memenuhi kriteria, maka dalam penelitian ini seluruh anggota populasi juga menjadi anggota dari sampel, sehingga penelitian ini disebut juga metode sensus (complete enumeration). Hasil analisis jalur (Path analysis) menunjukkan bahwa program ePPM-UKM secara langsung dan signifikan berpangaruh terhadap kemampuan manajemen dan kinerja manajemen, demikian pula kemampuan manajemen secara langsung dan signifikan berpengaruhi terhadap kinerja manajemen. Hasil penelitian ini menunjukkan bawah program ePPM-UKM yang diterapkan secara terstruktur maka kemampuan manajemen menjadi semakin kreatif dan inovatif, demikian pula kemampuan manajemen yang inovatif maka kinerja manajemennya menjadi lebih efektif dan efisien.
\end{abstract}

Kata kunci: ePPM-UKM; kemampuan; kinerja; manajemen; web

\section{PENDAHULUAN}

Propinsi Jawa Timur memiliki sekitar 6,9 juta UMKM yang tersebar di wilayah kota atau kabupaten namun pandemi covid-19 yang melanda Indonesia telah meruntuhkan pilar ekonomi masyarakat menjadi lumpuh 
bahkan banyak yang bangkrut. Interaksi usaha dengan pembeli dan masyarakat telah terkunci mati oleh situasi dan kondisi yang tidak pasti, karena kebijakan PSBB yang diterapkan oleh pemerintah pusat dan daerah tidak memberi alternatif solusi bagi dunia usaha. Khusus bagi UKM atau industri kreatif telah merasakan mati dalam hidup (tak berdaya) karena mata rantai usaha telah terputus. Ketidakmampuan para pelaku usaha dalam memanfaatkan akses sumberdaya teknologi menjadi salah satu faktornya (Okundaye et al., 2019). Beradaptasi dengan teknologi informasi dan aplikasinya merupakan jalan terbaik bagi dunia usaha agar tetap eksis (Prashar, 2019). Beberapa bukti emperis menunjukkan bahwa perusahaan yang memanfaatkan teknologi informasi dan aplikasinya untuk mengelola usaha justru dapat mengalami pertumbuhan yang positif saat terjadi situasi pandemi covid-19 (Okundaye et al., 2019; Prashar, 2019). Kelompok UKM yang mampu beradaptasi dengan teknologi informasi tentu memperoleh peluang yang luas untuk berperilaku kreatif dan inovatif dalam mengelola usahanya (Fitriati et al., 2020). Kemampuan manajemen telah teruji untuk menghadapi setiap kemungkinan yang terjadi di dalam bisnis (Maarof dan Mahmud, 2016). Kepemilikan pengetahuan yang mumpuni secara konseptual juga memberi kemampuan manajemen yang adaptif dengan setiap perubahan yang terjadi (Mulolli et al., 2017) dan pada gilirannya proses manajemen yang inovatif juga mampu memberi dampak pada kinerja manajemen yang efektif dan efisien bagi usahanya (Sawaean dan Ali, 2020).

Transformasi teknologi informasi dalam bentuk aplikasi web, mampu memberikan manfaat dan kemudahan untuk pengelolaan aktivitas manajemen (Okundaye et al., 2019). Jika hal ini diterapkan untuk dunia usaha tentu semua proses usaha akan berjalan lebih efektif dan efisien (Choi et al., 2019). Masyarakat UKM atau industri kreatif justru masih belum banyak yang memanfatkan teknologi informasi sebagai sumberdaya konseptual untuk mengelola usahanya (Okundaye et al., 2019). Perubahan situasi yang disebabkan oleh pandemi covid-19 tak mampu diselesaikan melalui tata kelola manajemen yang konvensional (Maarof dan Mahmud, 2016). Saatnya masyarakat UKM atau industri kreatif mulai beradptasi dengan teknologi informasi dan aplikasi lainya, sehingga perubahana pengelolaan usaha yang berorientasi pada pemanfaatan teknologi menjadi bagian konsep dalam pengembangan manajemen berkelanjutan (Goerzig dan Bauernhansl, 2018). Bisnis bukan bicara hari ini tetapi bagaimana bisnis mampu bertahan dan berkelanjutan (Chang dan Cheng, 2019), oleh karena itu sumberdaya ekonomi yang kuat bukanlah jaminan bisnis tetap mampu bertahan (Dolz et al., 2019). Kemampuan beradaptasi dengan perubahan justru menjadikan bisnis tetap hidup (Ombi et al., 2018) sedangkan berperilaku kreatif dan inovatif merupakan salah satu kunci sukses bagi masyarakat UKM atau industri kreatif (Falahat et al., 2020). Sumberdaya konseptual yang berwujud teknologi informasi dapat dimanfaatkan untuk mengelola seluruh aktivitas usahanya (Hassan dan Raziq, 2019), sehingga proses manajemen menjadi lebih efektif, kinerja manajemen menjadi efisien dan kinerja bisnis menjadi lebih baik (Ombi et al., 2018).

Mengacu pada berbagai hambatan yang dihadapi oleh masyarakat UKM atau industri kreatif atas kinerja usahanya yang turun secara drastis, maka perlunya dikaji secara mendalam atas permasalahan manajemen yang kurang mampu beradaptasi dengan perubahan, hal ini disebabkan oleh perilaku inovatif yang belum membudaya dalam menerapkan konsep dan fungsi manajemen didalam mengelola usahanya (Okundaye et al., 2019). Pemanfaatan akses teknologi informasi yang belum menjadi bagian budaya dalam mengelola usahanya juga memberi andil yang signifikan untuk ketahanan manajemen yang layak (Maarof dan Mahmud, 2016). Program Pengembangan Manajemen berbasis aplikasi (ePPM- 
UKM) merupakan suatu aplikasi yang didesain untuk memacu pengembangan kemampuan manajemen masyarakat UKM atau industri kreatif agar dapat bangkit kembali setelah terpuruk oleh pandemi covid-19. Program pelatihan dan pendampingan manajemen yang dilakukan secara terstruktur dan masif memberi kemampuan manajemen menjadi lebih baik (Dolz et al., 2019), hal ini disebabkan oleh proses transformasi pengetahuan manajemen terjadi secara efektif dan efisien (Lin dan Ho, 2019), sehingga masyarakat UKM atau industri kreatif mampu membangun budaya kreatif dan inovatif dalam menerapkan konsep dan fungsi manajemen usaha. Pemanfaatan sumberdaya konseptual akan menuntun mereka pada capaian kinerja manajemen yang lebih efektif dan efisien, oleh karena itu selama pendemi covid-19 kebangkitan masyarakat UKM atau industri kreatif harus didorong agar mereka segera lepas dari kesulitan usahanya. Keberadaan mereka diharapkan mampu memberi sumbangsih dalam membangkitkan sektor UKM, dimana secara riil telah memberi kontribusi dalam meningkatkan pendapatan dan kesejahteraan bagi masyarakat diwilayah tersebut.

Memasuki era industri 4.0 dan belajar pada pengalaman pandemi covid-19 sudah selayaknya jika pemangku kepentingan lebih fokus memberi edukasi kepada masyarakat dan dunia usaha agar lebih memahami dan akrab dengan teknologi informasi dan aplikasinya. Dalam rangka mendukung program RISTEK-BRIN yang menggagas "UKM Indonesia Bangkit" maka sudah sewajarnya jika sumberdaya intelektual yang ada dapat dioptimalkan untuk mengungkit kemampuan manajemen bagi pelaku UKM atau industri kreatif yang tersebar di wilayahnya. Model klusterisasi pengembangan kemampuan manajemen mereka merupakan satu alternatif yang dapat diimplementasikan melalui program ePPM-UKM maupun program-program aplikasi lainnya yang berbasis web sehingga dalam rangka beradaptasi dengan tatanan aktivitas baru (new normal life). Aktivitas masyarakat harus dapat berjalan kembali, demikian pula transformasi pengetahuan manajemen bagi UKM atau Industri kreatif dapat normal kembali melalui daring (web), oleh karena itu sudah saatnya untuk meningkatkan edukasi kemasyarakat terkait dengan kebutuhan beradaptasi dan mengenali cara pemanfaatan teknologi informasi sebagai bagian dari perilaku kreatif dan inovatif di dalam mengelola usahanya. Pelajaran paling berharga dari pandemi covid-19 bagi masyarakat UKM atau industri kreatif adalah kesadaran mereka untuk beradaptasi dan mengenal dengan baik akan hadirnya teknologi informasi atau jenis aplikasi lainnya yang dapat dimanfaatkan untuk mengelola usahanya. Teknologi informasi bukan lagi sebagai hambatan tetapi sudah menjadi mitra dan sahabat dekat yang terus berdampingan dengan bisnis mereka, oleh karena itu keikutsertaan dan partisipasi aktif mereka didalam implementasi program ePPM-UKM diharapkan mampu menjadi jembatan menuju kepemilikan kemampuan manajemen yang mumpuni agar mereka mampu mengelola usahanya dengan baik serta mampu beradaptasi dengan setiap kemungkinan terjadinya perubahan. Mengacu pada uraian tersebut di atas maka dapat dikemukanan rumusan masalah sebagai berikut: (1) Apakah implementtasi ePPM-UKM berpengaruh terhadap kemampuan manajemen UKM dan industri kreatif; (2) Apakah implementasi ePPM-UKM berpengaruh terhadap kinerja manajemen UKM dan industri kreatif; (3) Apakah kemampuan manajemen berpengaruh terhadap kinerja manajemen UKM dan industri kreatif. Tujuan penelitian ini adalah mengkaji dan membuktikan secara emperis: (1) Pengaruh implementasi ePPM-UKM terhadap kemampuan manajemen UKM dan industri kreatif; (2) Pengaruh implementasi ePPM-UKM terhadap kinerja manajemen UKM dan industri kreatif; (3) Pengaruh kemampuan manajemen terhadap kinerja manajemen UKM dan industri kreatif 


\section{TINJAUAN TEORETIS \\ Implementasi ePPM-UKM}

Implementasi ePPM-UKM merupakan aplikasi berbasis web yang diterapkan kepada sekelompok UKM atau industri kreatif yang mengalami goncangan usaha sebagai akibat riil dari pandemi covid-19 enam bulan yang lain. Aplikasi ini didesain untuk memenuhi kebutuhan atas permasalahan yang dihadapi oleh masyarakat dengan fokus pada pengembangan kemampuan manajemen, dimana didalamnya berisikan program pelatihan dan pendampingan, sedangkan kontennya terdiri dari aspek SDM, aspek manajemen pemasaran, aspek manajemen manufaktur, aspek manajemen keuangan atau akuntansi dan aspek teknologi informasi. Program pelatihan berorientasi pada transfer pengetahuan manajemen kepada pihak yang menjadi obyek pelatihan (Lin dan Ho, 2019; Prashar, 2019), sedangkan program pendampingan berorientasi pada penerapan hasil pelatihan langsung pada obyeknya (Prashar, 2019), sehingga terjadi transformasi yang mengkristal pada bentuk kemampuan manajemen yang dapat diterapkan pada penggunaan konsep dan fungsi manajemen didalam mengelola usahanya (Ahmadi dan Osman, 2018). Kemampuan manajemen yang berorientasi pada perilaku kreatif dan inovatif mampu memberi jawaban setiap terjadi perubahan (Maarof dan Mahmud, 2016), karena hakekat perubahan adalah kesiapan dalam memilih konsep baru yang sesuai dengan eranya, oleh karena itu perilaku kreatif dan inovatif selalu dibutuhkan untuk membawa perubahan (Hervas-Oliver et al., 2020). Bersahabat dengan perkembangan teknologi informasi dan penerapannya dalam aktivivitas usaha membutuhkan sebuah aplikasi yang sesuai dengan yang diperlukan (Okundaye et al., 2019), oleh karena itu akses terhadap sumberdaya konseptual harus selalu dipelihara sebagai investasi (Janasová et al., 2017). Investasi sumberdya konseptual merupakan salah satu kebutuhan investasi yang mutlak diperlukan di saat bisnis sudah tidak mampu di kendalikan lagi secara konvensional karena pembatasan oleh pandemi yang tidak mungkin bertemu secara langsung dengan pembeli atau konsumen, oleh karena itu pandemi covid19 telah memberi edukasi yang sangat berharga bagi masyarakat UKM atau industri kreatif agar senantiasa beradaptasi dengan perkembangan teknologi informasi atau aplikasi lain yang dapat mempermudahkan untuk mengelola usahanya baik untuk interaksi dengan pihak internal maupun dengan pihak pembeli, mitra dan transaksi lainnya, sehingga usahanya mampu meraih kinerja yang lebih baik.

Implementasi ePPM-UKM secara tidak langsung turut membangun budaya kreatif dan inovatif pada kelompok masyarakat UKM atau industri kreatif agar senantiasa belajar dengan perubahan, sedangkan komitmen pada teknologi informasi adalah kunci perubahan itu sendiri (Okundaye et al., 2019). Penerapan konsef dan fungsi manajemen merupakan representative dari kemampuan manajemen yang akan tercermin pada proses perbaikan manajemen secara berkelanjutan serta akses sumberdaya ekonomi yang luas (Chang dan Cheng, 2019; Prashar, 2019), sehingga mampu memperoleh input dan proses yang terbaik terkait dengan pengelolaan usahanya dan selanjutnya akan memberi kontribusi secara riil pada kinerja usaha menjadi lebih baik (Choi et al., 2019). Kinerja usaha ditentukan oleh kinerja manajemen yang efektif dan efisien, sedangkan kinerja manajemen ditentukan oleh proses manajemen yang inovatif dan kemampuannya dalam memanfaatkan sumberdaya konseftual (Felício et al., 2019; Sawaean dan Ali, 2020), oleh karena itu proses pengembangan manajemen merupakan suatu kebutuhan yang harus dipelihara agar usahanya tumbuh berkembang secara berkesinambungan serta selalu siap dalam menghadapi setiap perubahan (Chang dan Cheng, 2019). Pengembangan kemampuan manajemen dibutuhkan untuk memenuhi tantangan setiap perubahan hadir ditengah persaingan 
bisnis, baik yang memberi peluang maupun yang memberi hambatan bagi kemampuan manajemen dalam mengelola bisnisnya. Budaya kreatif dan inovatif di butuhkan saat bisnis menghadapi kejenuhan, persaingan semakin ketat, selera konsumen mulai berubah, oleh karena itu kemampuan inovasi dalam manajemen maupun inovasi dalam pengelolaan dalam produk atau jasa akan membuka peluang yang lebih baik dibanding mereka yang tidak melakukannya (Choi et al., 2019).

Berbagai kajian tersebut menunjukkan bahwa bisnis di era new normal life membuka peluang yang terbuka untuk menggiatkan kembali berbagai aktivitas UKM atau industri kreatif melalui pemanfaatan teknologi informasi atau program aplikasi lainnya. Masyarakat dan dunia usaha dapat memulai beraktivitas kembali di tengah pandemi covid-19 jika mereka mampu beradaptasi dengan teknologi informasi dan memanfaatkannya untuk mengelola usahanya, sehingga mereka mampu berperilaku kreatif dan inovatif untuk menghasilkan proses manajemen yang efektif serta menghasilkan kinerja yang baik. Setiap pelaku UKM atau industri kreatif memiliki peluang yang sama dalam menghadapi perubahan, namun mereka memiliki kemampuan yang berbeda dalam menyikapinya, oleh karena itu hasil akhir dari suatu proses akan menentukan kinerja yang berbeda, hal ini tergantung pada kemampuan manajemen dalam mengelola input, mengelola proses melalui pemanfaatan sumberdaya yang efektif dan efisien. Mengacu pada uraian tersebut maka dapat diajukan hipotesis sebagai berikut:

$\mathrm{H}_{1}$ : Implementasi ePPM-UKM berpengaruh signifikan terhadap kemampuan manajemen UKM dan industri kreatif

$\mathrm{H}_{2}$ : Implementasi ePPM-UKM berpengaruh signifikan terhadap kinerja manajemen UKM dan industry kreatif

\section{Kemampuan Manajemen}

Kemampuan manajemen merupakan kepemilikan pengetahuan yang diperoleh melalui proses terstruktur dan sistematis yang terwujud dalam konsep dan fungsi manajemen yang dapat digunakan untuk mengelola aktivitas usahanya. Kemampuan manajemen akan mengkristal dalam wujud budaya kreatif dan inovatif didalam menggunakan sumberdaya ekonomi dan sumberdaya konseptual (Henriques dan Catarino, 2016), sehingga menghasilkan proses manajemen yang efektif serta luaran yang efisien (Lin dan Ho, 2019). Situasi bisnis yang tidak menentu serta perubahan yang sangat cepat diperlukan tingkat responsif yang cepat pula, agar usahanya tetap eksis dan berkelanjutan (Prashar, 2019), oleh karena itu pengembangan kemampuan manajemen bukan sekedar kebutuhan tetapi merupakan investasi yang diperlukan untuk menjamin keberlanjutan usahanya (Prashar, 2019). Perubahan adalah hal yang pasti namun kemampuan menghadapi perubahan bukanlah hal yang pasti, namun membutuhkan respon yang cepat serta tercermin pada perilaku kreatif dan inovatif didalam menerapkan konsep dan fungsi manajemennya (Fitriati et al., 2020) sehingga mampu menciptakan kinerja manajemen yang efektif (Sawaean dan Ali, 2020). Pemilihan sumberdaya yang tepat juga merupakan bagian penting dalam proses bisnis (Felício et al., 2019), oleh karena itu koordinasi antar fungsi yang ada didalam proses membutuhkan kecermatan didalam manajemen, sedangkan kemampuan beradaptasi dengan perubahan juga menuntut proses perbaikan manajemen secara terstruktur dan masif (Lin dan Ho, 2019).

Kemampuan manajamen diperlukan untuk mempersiapkan diri agar usahanya mampu menghadapi perubahan (Maarof dan Mahmud, 2016), sedangkan perubahan bukan hal yang harus dihindari tetapi bagaimana cara menghadapinya agar ditemukan solusi terbaiknya (Ahmadi dan Osman, 2018). Melalui proses perbaikan manajemen secara berkelanjutan maka kemampuan manajemen akan semakin 
adaptif dengan perubahan (Chang dan Cheng, 2019), sedangkan perubahan yang dinamis juga diperlukan oleh manajemen agar selalu menghasilkan inovasi yang selaras dengan kebutuhan dan keinginan perubahan itu sendiri (Maarof dan Mahmud, 2016), oleh karena itu kinerja proses sangat menentukan kinerja hasil, sedangkan kinerja hasil akan menentukan kinerja bisnis. Input, proses dan output didalam manajemen merupakan mata rantai yang saling terkait satu dengan yang lain (Choi et al., 2019). Proses perbaikan secara berkelanjutan dapat mendorong kemampuan manajemen untuk siap menciptakan kreativitas dan inovasi yang diperlukan untuk beradaptasi dengan perubahan serta mampu menghasilkan kinerja menjadi lebih baik (Sawaean dan Ali, 2020). Kemampuan manajemen tidak dapat diperoleh secara alami tetapi memerlukan suatu proses secara terstruktur, sistematis dan berkesinambungan, namun melalui proses bisnis dalam kurun waktu yang cukup akan mampu memberi satu pembelajaran bisnis bagi mereka, tetapi hal ini tidak menjamin kemampuan manajemen mereka siap menghadapi perubahan (Chang dan Cheng, 2019), oleh karena itu perubahan harus disikapi melalui perilaku kreatif dan inovatif serta kemampuannya dalam memanfaatkan sumberdaya yang berorientasi pada teknologi informasi secara tepat dan efektif. Berbagai kajian tersebut menunjukkan bahwa kemampuan manajemen bukanlah hal yang berdiri sendiri tetapi suatu konsep yang dapat dikembangkan melalui proses terstruktur dan sistematis, oleh karena itu kemampuan manajemennya harus dipelihara secara berkelanjutan, agar eksistensinya dapat dimanfaatkan untuk mengelola usahanya sekaligus memanfaatkan sumberdaya ekonomi yang dimilikinya secara efektif dan efisien, agar mereka mampu untuk beradaptasi dengan setiap perubahan yang mungkin terjadi serta mampu meraih kinerja menjadi lebih baik. Mengacu pada uraian tersebut maka dapat dikemukakan hipotesis sebagai berikut:
$\mathrm{H}_{3}$ : Kemampuan Manajemen berpengaruh signifikan terhadap Kinerja Manajemen UKM dan industri kreatif

\section{Kinerja Manajemen}

Kinerja manajemen merupakan hasil akhir dari proses manajemen melalui penerapan konsep dan fungsi manajemen di dalam mengelola usahanya (Sawaean dan Ali, 2020), sedangkan proses manajemen merupakan serangkaian pemilihan sumberdaya ekonomi dan sumberdaya konseptual yang dibutuhkan untuk menjalankan proses bisnis (Fitriati et al., 2020), oleh karena itu capaian kinerja manajemen yang baik membutuhkan kemampuan manajemen yang baik pula (Hervas-Oliver et al., 2020), dimana kemampuan didalam mengembangkan perilaku kreatif dan inovatif dalam menerapkan konsep dan fungsi manajemen harus didukung oleh kepemilikan pengetahuan yang memadai (Hassan dan Raziq, 2019). Sumberdaya konseptual yang berupa teknologi informasi serta penerapannya dalam bentuk aplikasi merupakan sebuah instrumen yang sering dimanfaatkan untuk mengelola sumberdaya lainnya maupun proses fungsi aktivitas yang ada didalam bisnis (Ahmadi dan Osman, 2018), oleh karena itu teknologi informasi dan aplikasi berbasis web memiliki andil yang sangat kuat untuk membangun kinerja manajemen maupun proses manajemen yang efektif.

Kinerja manajemen bukanlah tujuan akhir, namun sebagai sasaran antara untuk meraih kinerja bisnis yang lebih baik (Sawaean dan Ali, 2020), agar manajemen tidak terobsesi pada hasil akhir namun lebih berfokus pada proses. Proses manajemen yang didukung oleh kemampuan manajemen yang memadai jauh lebih penting dari hasil akhir dari suatu proses (Falahat et al., 2020) karena hasil akhir suatu proses bersifat pasif yaitu ditentukan, sedangkan proses manajemen bersifat aktif yaitu menentukan (Ombi et al., 2018), oleh karena itu untuk meraih 
kinerja yang baik dibutuhkan proses manajemen yang baik melalui perilaku kreatif dan inovatif didalam menggunakan pilihan konsep dan fungsi manajemen serta pemanfaatan sumberdaya konseptual yang efektif (Choi et al., 2019), sehingga bisnis selalu mampu beradaptasi dengan perubahan yang bersifat dinamis (Maarof dan Mahmud, 2016). Kinerja Manajemen merupakan upaya untuk membangun pengembangan konsep dan pemanfaatan fungsi fungsi manajemen untuk pengelolaan usahanya yang mengarah pada perilaku kreatif dan inovatif dalam memanfaatan sumberdaya ekonomi yang lebih efektif dan efisien, sehingga mampu menghasilkan kinerja unit atau usaha menjadi lebih baik dan berkesinambungan. Teknologi informasi memegang kendali yang sangat strategis dalam rangka mengelola sumberdaya pisik maupun sumberdaya ekonomi lainnya yang dapat tercermin pada pengendalian aktivitas usaha melalui perangkat aplikasi berbasis web atau online, oleh karena itu investasi dibidang teknologi informasi jangan dipandang sebagai beban masa kini tetapi harus diperlakukan sebagai aset masa depan yang memiliki manfaat tak terbatas walaupun karakteristis teknologinya bersifat terbatas yang disebabkan oleh perubahan teknologi itu sendiri yang sifatnya dinamis, bernilai inovatif serta lebih memberi manfaat yang lebih efektif dan efisien (Falahat et al., 2020).

Hubungan dari berbagai teori yang dianalisis secara kritis, sistematis serta sintesa tentang hubungan variabel terdiri implementasi ePPM-UKM, kemampuan manajemen dan kinerja manajemen, diharapkan mampu merekonstruksi tentang upaya bagaimana meraih kinerja manajemen menjadi lebih baik. Program ePPMUKM yang diimplementasikan secara terstruktur dan masif, akan turut meningkatkan kemampuan manajemen yang lebih kreatif dan inovatif didalam menerapkan konsep dan fungsi manajemen, selanjutkan kemampuan manajemen yang selalu siap beradaptasi dengan perubahan akan mendukung capaian kinerja manajemen menjadi lebih baik (Maarof dan Mahmud, 2016; Sawaean dan Ali, 2020). Oleh karena itu kinerja manajemen harus didesain secara komprehensif melalui pengembangan kemampuan manajemen serta melakukan pemilihan sumberdaya ekonomi dan sumberdaya konseftual yang sesuai dengan tujuan dan kebutuhan bisnisnya, meskipun dalam realitanya bisnis dan tujuan selalu berubah selaras dengan perubahan pada eranya, sehingga diperlukan kemampuan beradaptasi dengan perubahan lingkungannya baik menyangkut perubahan input, perubahan proses maupun perubahan output dan outcomenya (Maarof dan Mahmud, 2016; Sawaean dan Ali, 2020). Program ePPMUKM merupakan salah satu aplikasi berbasis web yang dirancang untuk memenuhi kebutuhan masyarakat UMK atau industri kreatif yang saat ini sedang mengalami kesulitan untuk mengaktifkan kembali usahanya selama covid-19 karena belum terbiasa dengan penggunaan aplikasi web dalam mengelola usahanya, oleh karena itu melalui program ePPMUKM, maka akan diperoleh suatu transfer pengetahunan baru sekaligus dapat mengikuti materi program pengembangan kemampuan manajemen yang ditawarkan melalui program pelatihan dan pendampingan manajemen secara terstruktur dan masif (Choi et al., 2019).

\section{METODE PENELITIAN Rancangan Penelitian}

Penelitian ini termasuk jenis penelitian ekplanatif atau asosiatif yang disertai dengan pengujian hipotesis. Penelitian ini ingin menguji pengaruh implementasi ePPM-UKM terhadap nilai kemampuan manajemen dan kinerja manajemen serta menguji pengaruh kemampuan manajemen terhadap nilai kinerja manajemen, penelitian ini juga termasuk jenis perseptional (perception research) karena datanya diper- 
oleh melalui persepsi dari responden atas jawaban dari butir butir pertanyaan yang tersedia didalam kueisoner.

\section{Populasi}

Populasi dalam penelitian ini adalah pelaku UKM dan industri kreatif yang telah mengikuti program implementasi ePPM-UKM selama pandemi covid-19, tersebar di lima wilayah kota atau kabupaten yaitu Sidoarjo, Surabaya, Lamongan, Gresik dan Tuban, aktif berusaha minimal lima tahun sampai akhir bulan Juni 2020, pelaku usaha sekaligus sebagai pemilik. Berdasarkan kriteria tersebut terdapat 60 pelaku UKM atau industri kreatif yang memenuhi persyaratan sebagai populasi, karena jumlah anggota populasi sangat terbatas, maka dalam penelitian ini seluruh anggota populasi juga sebagai anggota sampel sehingga penelitian ini disebut juga dengan metode sensus (complete enumeration).

Model Analisis

\section{Definisi Operasional Variabel}

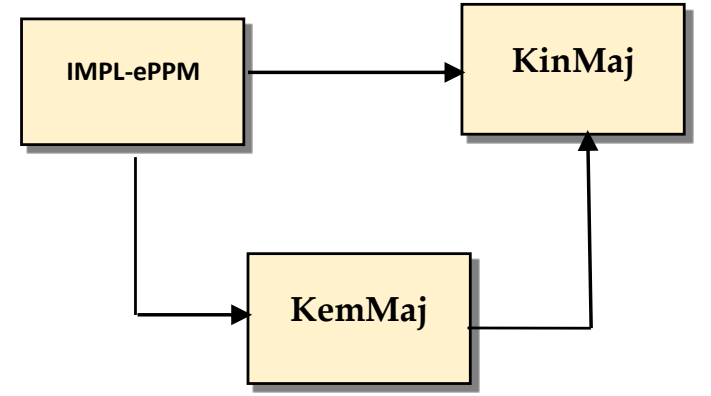

Gambar 1

Model Path Analysis

Sumber: Modifikasi oleh penulis

Keterangan:

IMPL-ePPM : Variabel bebas (X)

KemMaj : Variabel terikat atau intervening $(\mathrm{Z})$

KinMaj : Variabel terikat $(Y)$

Model Path analysis menggambarkan adanya pengaruh langsung MPL-ePPM terhadap KinMaj dan KemMaj, demikian pula KemMaj terhadap KinMaj, sedang IMPL-ePPM memiliki pengaruh tidak langsung terhadap KinMaj melalui KemMaj.

Tabel 1

Definisi Operasional Variabel

\begin{tabular}{|c|c|c|c|}
\hline No & Variabel & Definisi Operasional & Indikator \\
\hline 1 & $\begin{array}{l}\text { Implementasi } \\
\text { ePPM-UKM } \\
\text { (IPLM-ePPM) }\end{array}$ & $\begin{array}{l}\text { Penerapan Aplikasi ePPM- } \\
\text { UKM pada kelompok UKM dan } \\
\text { industri kreatif secara online } \\
\text { atau berbasis web sebagai } \\
\text { upaya menambah pengetahuan } \\
\text { yang bermanfaat untuk me- } \\
\text { ningkatkan pengembangan ke- } \\
\text { mampuan manajemennya }\end{array}$ & $\begin{array}{l}\text { 1. Komitmen } \\
\text { mengembangkan } \\
\text { manajemen } \\
\text { 2. Program pelatihan } \\
\text { 3. Program pendampingan } \\
\text { 4. Menerapkan bisnis berbasis } \\
\text { aplikasi web atau online } \\
\text { 5. Mengembangan IT dalam } \\
\text { proses bisnis } \\
\text { 6. Aplikasi yang adaptif }\end{array}$ \\
\hline 2 & $\begin{array}{l}\text { Kemampuan } \\
\text { Manajemen } \\
\text { (KemMaj) }\end{array}$ & $\begin{array}{l}\text { Kepemilikan pengetahuan } \\
\text { manajemen pada pelaku UKM } \\
\text { dan industri kreatif didalam } \\
\text { menerapkan konsef dan fungsi } \\
\text { manajemen untuk pengelolaan } \\
\text { sumberdaya dan usahanya } \\
\text { secara efektif dan inovatif }\end{array}$ & $\begin{array}{l}\text { 1. Eksekusi fungsi manajemen } \\
\text { 2. Respon terhadap } \\
\text { perubahan } \\
\text { 3. Penerapan aspek } \\
\text { manajemen } \\
\text { 4. Proses perbaikan } \\
\text { manajemen }\end{array}$ \\
\hline
\end{tabular}




Kinerja
Manajemen
(KinMaj)

Hasil akhir dari proses manajemen secara efektif dan efisien selama periode tertentu atas penerapan konsef dan fungsi manajemen serta sumberdaya pengetahuan manajemen untuk pengembangan usahanya.
5. Pemilihan sumberdaya ekonomi atau konseftual

6. Koordinasi antar fungsi

1. Pengambilan keputusan yang efektif

2. Proses bisnis yang efektif

3. Akses sumberdaya ekonomi yang luas

4. Penggunaan sumberdaya yang efisien

5. Produk yang inovatif

6. Efisiensi biaya

Sumber: Ahmadi dan Mohd. Osman, 2018; Chang dan Cheng, 2019; Choi, Thangamani, dan Kissock, 2019; Dolz, Iborra, dan Safón, 2019; Falahat, Ramayah, Soto-Acosta, dan Lee, 2020; Felício, Caldeirinha, dan Dutra, 2019; Fitriati, Purwana, dan Buchdadi, 2020; Goerzig dan Bauernhansl, 2018; Hassan dan Raziq, 2019; Henriques dan Catarino, 2016; Hervas-Oliver, Sempere-Ripoll, Boronat-Moll, dan Estelles-Miguel, 2020; Janasová, Bobáňová, dan Strelcová, 2017; Lin dan Ho, 2019; Maarof dan Mahmud, 2016; Mulolli, Islami, dan Skenderi, 2017; Okundaye, Fan, dan Dwyer, 2019; Ombi, Ambad, dan Bujang, 2018; Prashar, 2019; Sawaean dan Ali, 2020; Verdolini, Bak, Ruet, dan Venkatachalam, 2018.

\section{Instrumen Penelitian}

Pengumpulan data dalam penelitian ini menggunakan instrumen kuisioner yaitu menyusun item-item pertanyaan yang harus diisi oleh pelaku UKM dan industri kreatif yang tersebar di lima wilayah kota atau kabupaten di Jawa Timur yang memenuhi kriteria sebagai anggota populasi. Kuisioner sebagai instrumen harus memenuhi syarat validitas dan reliabilitasnya.

Validitas dalam penelitian ini menggunakan formula koefisien korelasi product-moment pearson dan reliabititas menggunakan cronbach's alpha. Suatu instrumen dinyatakan valid jika koefisien korelasinya positif dan signifikan dengan nilai correlated item-total correlation lebih besar dari nilai 0,30 dan instrumen dinyatakan reliabel jika nilai cronbach's alpha lebih besar dari nilai 0,6

\section{Prosedur Pengumpulan Data}

Pengumpulan data dilakukan melalui dua tahapan, yaitu (1) pengumpulan data primer (primary data) yang dikumpulkan secara langsung dari responden, (2) pengumpulan data sekunder (secondary data) yang diperoleh secara langsung dari sumber terpercaya lainnya khususnya untuk melengkapi dan memperkuat data tersebut.

\section{ANALISIS DAN PEMBAHASAN Validitas dan Realibilitas}

Tabel 2 menunjukkan bahwa koefisien korelasi semua variabel memiliki nilai rhitung antara 0,4173-0,8185 dengan nilai yang positip dan lebih besar dari 0,30. Demikian pula nilai Cronbach Alpha ketiga variabel memiliki nilai antara $0,7726-0,8364$ dengan nilai lebih besar dari 0,60. Nilai koefisien korelasi dan Cronbach Alpha tersebut menunjukkan bahwa instrumen penelitian yang digunakan untuk pengumpulan data penelitian adalah valid dan reliabel, oleh karena instrument telah memenuhi persyaratan validitas dan reliabel maka data yang dikumpulkan tersebut layak untuk menguji dan membuktikan hipotesis melalui uji statistik.

\section{Analisis Jalur (Path Analysis)}

Hasil pengujian linieritas merujuk pada konsep parsimony, yaitu bilamana seluruh model yang digunakan sebagai dasar pengujian adalah signifikan atau nonsignifikan berarti model dikatakan linier 
atau fungsi linier adalah signifikan. Hasil pengujian asumsi linieritas untuk setiap pengaruh antar variable dapat ditampilkan dalam Tabel 3.

Tabel 2

Hasil Uji Validitas dan Reliabilitas

\begin{tabular}{lccc}
\hline \hline Variabel & Koefisien Korelasi & $\begin{array}{c}\text { Cronback } \\
\text { Alpha }\end{array}$ & Keterangan \\
\hline Implementasi ePPM-UKM & $0,4621-0,7824$ & 0,7726 & Valid dan Reliabel \\
Kemampuan Manajemen & $0,4183-0,8185$ & 0,8364 & Valid dan Reliabel \\
Kinerja Manajemen & $0,4173-0,7932$ & 0,7734 & Valid dan Reliabel
\end{tabular}

Sumber: Print out pengolahan data

Tabel 3

Hasil Pengujian Asumsi Linieritas

\begin{tabular}{lll}
\hline \hline IndependentVariable & Dependent Variable & Hasil Pengujian $(\mathbf{a}=\mathbf{0 , 0 5})$ \\
\hline Implementasi ePPM-UKM & Kemampuan Manajemen & Model liner signifikan \\
Implementasi ePPM-UKM & Kinerja Manajemen & Model liner signifikan \\
Kemampuan Manajemen & Kinerja Manajemen & Model liner signifikan \\
\hline
\end{tabular}

Sumber: Print out pengolahan data

Tabel 3 menunjukkan bahwa semua bentuk pengaruh antar variabel di dalam model struktural adalah linier, dengan demikian asumsi linieritas pada path analysis terpenuhi

\section{Model Struktural}

Path analysis dilakukan dengan standardize regression menggunakan software Statistical Product and Service Solutions (SPSS) Versi 22. Hasil pengujian koefisien jalur pengaruh langsung dapat disajikan pada Tabel 4, sedangkan pengaruh secara tidak langsung dapat disajikan pada Table 5.

Tabel 4

The Summary of Regression

\begin{tabular}{|c|c|c|c|}
\hline IndependentVariable & Dependent Variable & Koefisien Standardize & Sig. (0.05) \\
\hline $\begin{array}{l}\text { Implementasi } \\
\text { ePPM-UKM }\end{array}$ & $\begin{array}{l}\text { Kemampuan } \\
\text { Manajemen }\end{array}$ & 0,4372 & 0,032 \\
\hline $\begin{array}{l}\text { Implementasi } \\
\text { ePPM-UKM }\end{array}$ & $\begin{array}{l}\text { Kinerja } \\
\text { Manajemen }\end{array}$ & 0,3818 & 0,046 \\
\hline $\begin{array}{l}\text { Kemampuan } \\
\text { Manajemen }\end{array}$ & $\begin{array}{l}\text { Kinerja } \\
\text { Manajemen }\end{array}$ & 0,4386 & 0,038 \\
\hline
\end{tabular}

Sumber: Print out pengolahan data

Tabel 5

Indirect Effect Path Coefficient

\begin{tabular}{lllc}
\hline Independent Variable & Intervening Variable & $\begin{array}{l}\text { Dependent } \\
\text { Variable }\end{array}$ & $\begin{array}{c}\text { Koefisien } \\
\text { Standardize }\end{array}$ \\
\hline $\begin{array}{l}\text { Implementasi } \\
\text { ePPM-UKM }\end{array}$ & $\begin{array}{l}\text { Kemampuan } \\
\text { Manajemen }\end{array}$ & $\begin{array}{l}\text { Kinerja } \\
\text { Manajemen }\end{array}$ & $0,1918$ (sig. a $=0,05)$ \\
\hline
\end{tabular}




\section{Pengaruh Implementasi ePPM-UKM Terhadap Kemampuan Manajemen}

Implementasi ePPM-UKM merupakan aplikasi berbasis web yang memiliki konten terkait dengan pengembangan manajemen bagi pelaku UKM dan industri kreatif, dimana selama pandemi covid-19 aktivitas usaha mereka menjadi berhenti karena terputusnya interaksi dengan pembeli yang selama ini di lakukan secara konvensional. Program implementasi ePPM-UKM pada UKM dan industri kreatif memberi kesempatan baginya untuk mengikuti program pelatihan dan program pendampi ngan secara langsung atau yang berbasis aplikasi, sehingga dapat meningkatkan kemampuan manajemennya dalam mengelola usahanya secara efektif dan inovatif, sehingga dapat mendorong kebangkitan usahanya kembali seperti sebelum terjadi covid-19. Aplikasi ePPM-UKM memiliki dua program utama yaitu program pelatihan dan program pendampingan, sedangkan kontennya meliputi aspek SDM, aspek manajemen pemasaran, aspek manajemen manufaktur, aspek manajemen keuangan atau akuntansi dan aspek teknologi informasi. Keikutsertaan mereka secara aktif tentunya dapat meningkatkan kemampuan manajemennya dan selanjutnya dapat dipergunakan untuk mengelola dan mengembangkan usahanya secara terstruktur dan masif. Komitmen dalam pengembangan manajemen memberi dorongan terhadap partisipasi mereka untuk menjadi bagian dalam program implementasi ePPMUKM pada UKM atau industri kreatif secara terstruktur, maka akan terjadi proses transformasi pengetahuan manajemen, sehingga kemampuan manajemennya akan meningkat lebih baik, pengelolaan usahanya menjadi semakin efektif dan inovatif terutama dalam memanfaatkan teknologi informasi dan aplikasi bisnis lain secara online, oleh karena itu implementasi ePPMUKM sebagai produk teknologi tepat guna dapat diterapkan untuk pengembangan kemampuan manajemen UKM dan industri kreatif, sehingga kemampuan mereka di- dalam mengelola usahanya akan menjadi semakin efektif dan inovatif melalui melalui penerapan aplikasi berbasis webatauonline yang saat covid-19 mengalami titik kritis didalam usahanya karena kebuntuan interaksi dengan pembelinya.

ePPM-UKM sebagai produk teknologi tepat guna didesain dalam rangka memberi transfer pengetahuan kepada masyarakat UKM atau industri kreatif dalam upaya untuk meningkatkan kemampuan manajemennya, dimana selama pandemi covid19 mengalami hambatan dalam mengelola usahanya bahkan nyaris mengalami kebangkrutan. Transfer pengetahuan dirasa sebagai salah satu yang penting untuk mengatasi kebuntuan usaha mereka selama ini, oleh karena itu menimbulkan komitmen yang sangat kuat di tengah masyarakat UKM atau industri kreatif untuk mengikuti program pengembangan kemampuan manajemen melalui implementasi ePPMUKM. Komitmen mengembangkan manajemen bukanlah sesuatu yang harus dipaksakan lagi, tetapi sudah dirasakan sebagai kebutuhan agar mereka dapat keluar dari kesulitan dalam mengelola usahanya, terutama bagaimana memahami konsef dan menerapkan fungsi manajemen didalam bisnisnya. Upaya konkrit didalam program ePPM-UKM adalah melakukan proses transfer pengetahuan manajemen melalui aplikasi berbasis web, sehingga mereka dapat mengikuti program pengembangan manajemen tanpa harus meningggalkan aktivitas usahanya yang saat ini sedang melakukan proses penyehatan manajemennya agar mampu menuju kebangkitannya kembali setelah hampir enam bulan dirundung kelesuan usaha. Kemampuan manajemen yang diperoleh melalui proses yang terstruktur dan masif tentu akan memberi proses pembelajaran bisnis yang terstruktur pola sehingga mereka mampu menerapkan konsef dan fungsi manajemen sesuai dengan kebutuhan yang diinginkan oleh masyarakat UKM atau industri kreatif dalam pengembangan usahanya ditengah pandemi covid-19 
hingga saat sekarang. ePPM-UKM melalui aplikasinya menawarkan program kepada masyarakat UKM dan industri kreatif agar mereka tetap membenahi manajemen usahanya sambil mengikuti program pelatihan manajemen sekaligus mengikuti program pendampingan hasil pelatihan yang mereka peroleh, sehingga terjadi proses adaptasi dan proses interaksi antara pihak masyarakat UKM atau industri kreatif dengan pihak pengelola program ePPMUKM agar dapat ditemukan formula yang sesuai dengan kebutuhan dan karakteristik dari masing masing pelaku UKM. Proses pendampingan umumnya mengalami proses yang lebih lama dibanding program pelatihan, karena didalam program pendampingan terjadi interaksi secara langsung dengan realita yang dihadapi oleh pelaku UKM, sehingga terjadi proses pemilihan metode yang benar benar sesuai dengan kebutuhannya, oleh karena itu terjadi proses evaluasi dan monitoring secara berkesinambungan dalam upaya untuk menghasilkan kemampuan manajemen yang dibutuhkan untuk menyelesaikan persoalan yang muncul didalam bisnisnya, sekaligus untuk pengembangan bisnis secara berkelanjutan, sehingga bisnis UKM bukan sekedar eksis tetapi mampu tumbuh berkembang ditengah persaingan yang semakin dinamis.

Program ePPM-UKM juga memberi peluang yang sangat luas kepada masyarakat UKMatauindustri kreatif untuk mengenal teknologi informasi melalui aplikasi berbasis webatau online, karena selama pandemi covid-19 bisnis yang dapat eksis hanya mereka yang mampu memanfaatkan berbagai aplikasi didalam pengelolaan bisnisnya, oleh karena itu komitmen pelaku UKM atau industri kreatif pada aspek teknologi informasi akan memberikan pondasi yang semakin kokoh didalam pengembangan kemampuan manajemennya. Seiring dengan perkembangan bisnis yang berorientasi pada pemanfaatan teknologi informasiatauaplikasi berbasis web, maka pengembangan kemampuan manajemen bukan berfokus pada konsep dan fungsi manajemen saja, tetapi lebih berorientasi pada pemanfaatan teknologi informasi untuk pengelolaan usaha maupun fungsi manajemennya, oleh karena itu implementasi ePPM-UKM kepada masyarakat UKM atau industri kreatif yang dilakukan secara terstruktur dan masif, tentu akan terjadi proses transfer pengetahuan yang layak bagi pengembangan kemampuan manajemen mereka, utamanya didalam upaya mengedukasi cara pemanfaatan teknologi informasi maupun jenis aplikasi lainnya untuk pengelolaan usahanya, baik disaat pandemi covid-19 masih berlangsung hingga sekarang maupun untuk menghadapi proses perubahan dan tantangan bisnis yang mungkin terjadi dimasa mendatang. Hasil temuan dalam penelitian ini: (1) terdapat pengaruh langsung implemenntasi ePPM-UKM terhadap kemampuan manajemen yang positip dan signifikan; (2) terdapat pengaruh tidak langsung nilai ePPM-UKM terhadap kinerja manajemen melalui kemampuan manajemen yang positif dan signifikan.

\section{Pengaruh Implementasi ePPM-UKM terhadap Kinerja Manajemen}

ePPM-UKM sebagai produk teknologi tepat guna merupakan format aplikasi berbasis web yang didesain dengan konten untuk pengembangan manajemen bagi pelaku UKM dan industri kreatif, dimana selama pandemi covid-19 kinerja manajemennya mengalami penurunan karena kreativitas dan inovasi didalam memanfaatkan sumberdaya teknologi untuk mewujudkan fungsi manajemennya masih belum optimal. Program ePPM-UKM dan implementasinya memberi kesempatan baginya untuk mengikuti program pelatihan dan program pendampingan secara langsung atau yang berbasis aplikasi, sehingga mampu memilih sumberdaya teknologi yang aplikatif dan sesuai dengan kebutuhannya. Partisipasi yang aktif tentunya dapat meningkatkan kemampuan manajemennya didalam memilih teknologi 
informasi yang sesuai untuk pengembangan usahanya. Komitmen dan adaptasi mereka dengan teknologi informasi dan aplikasi web lainnya tentu akan memberi dorongan yang kuat untuk menjadi bagian dalam program implementasi ePPM-UKM secara massif. Transformasi pengetahuan teknologi informasi dan aplikasi berbasis web turut memberi andil dalam membangun budaya dan perilaku kreatif dan inovatif didalam mengelola usahanya sehingga aktivitas usahanya menjadi semakin efektif dan efisien, oleh karena itu implementasi ePPMUKM sebagai produk teknologi tepat guna turut menjadi bagian dalam membangun proses manajemen untuk mengelola usahanya, sehingga proses manajemen yang inovatif akan menghasilkan keputusan yang efektif, proses bisnis lancar, akses sumberdaya semakin luas, penggunaan sumberdaya semakin efisien, produk semakin inovatif dan biaya semakin efisien, hal ini menunjukkan bahwa kinerja manajemen menjadi semakin baik manakala pelaku usaha berkomitmen untuk menjadi bagian dalam program implementasi ePPM-UKM secara terstruktur dan masif.

ePPM-UKM merupakan salah satu aplikasi berbasis web yang didesain untuk memberi pemahaman pengetahuan kepada masyarakat UKMatauindustri kreatif dalam rangka untuk meningkatkan kemampuan manajemennya, karena sejak pandemi covid-19 melanda Indonesia mereka mengalami kesulitan didalam mengelola usahanya bahkan nyaris tutup semua. Transfer pengetahuan sangat membantu didalam mengembangkan pengelolaan usaha yang lebih terstruktur dan sistematis, oleh karena itu proses pengambilan keputusan menjadi lebih akurat, sehingga kelompok UKMatauindustri kreatif yang mengikuti program pengembangan kemampuan manajemen melalui implementasi ePPM-UKM telah merasakan manfaatnya untuk meraih hasil usaha menjadi lebih baik. Komitmen dalam pengembangan manajemen merupakan satu dorongan yang positif untuk berpartisipasi secara aktif didalam mengikuti setiap program pelatihan dan pendampingan, sehingga secara langsung mereka dapat beradaptasi kembali dengan pola bisnis ditengah pendemi covid19 yang masih dirasakan hingga hari ini, terutama dalam memanfaatkan peran teknologi informasi dan aplikasi lain yang dipergunakan didalam pengelolaan bisnis. Kemampuan beradaptasi dengan tata kehidupan baru didalam bisnis (new normal life) diharapkan mampu memberi dorongan kuat untuk selalu berperilaku kreatif dan inovatif, sehingga proses bisnis menjadi efektif, pemanfaatan sumber daya ekonomi menjadi efisien, produk menjadi inovatif, biaya menjadi efisien, hal ini tentu akan terus berproses menjadi lebih baik dan berkelanjutan, manakala mereka tetap berkomitmen melakukan pengembangan kemampuan manajemen melalui partisipasinya mengikuti implementasi program ePPM-UKM secara terstruktur dan sistematis.

ePPM-UKM sebagai aplikasi berbasis web memberikan satu transfer pengetahuan yang dapat diselaraskan dengan kebutuhan manajemen dari masing-masing UKM atau industri kreatif yang memiliki karakteristik permasalahan yang berbeda pula, oleh karena itu untuk mendorong capaian kinerja manajemen yang lebih riil, sebaiknya terus berpartisipasi aktif dalam implementasi program ePPM-UKM secara terstruktur dan masif, agar pengembangan kemampuan manajemennya terus berlangsung secara berkesinambungan, sekaligus selalu menyiapkan diri untuk dapat beradaptasi dengan perubahan lingkungannya. Pengelolaan bisnis dengan memanfaatkan teknologi informasi atau aplikasi berbasis web akan memberi kesempatan untuk menguasasi ruang bisnis yang lebih luas dan cepat, sehingga semua proses manajemen dapat dilakukan lebih efektif dan efisien, bahkan proses bisnispun dapat dilakukan melalui media informasi tanpa harus melakukan kontak langsung secara pisik. Penyediaan ruang media berbasis aplikasiatauonline akan memudahkan inter- 
aksi antara konsumen dengan pemilik bisnis tanpa harus bertemu, namun semua pihak dapat berinteraksi melalui ruang tersebut sesuai dengan kebutuhan dan keinginan masing-masing, oleh karena itu kemampuan dalam menyajikan informasi bisnis melalui aplikasi web memerlukan inovasi yang sesuai dengan kebutuhan pasar masing-masing. Aplikasi berbasis web sebagai alat bantu manajemen memerlukan penyesuain dengan proses bisnis yang berlangsung secara berkelanjutan, baik karena adanya perubahan faktor internal maupun perubahan faktor eksternal, di mana setiap faktor tentu memiliki tingkat pengaruh yang berbeda terhadap perubahan yang terjadi.

Program ePPM-UKM akan berjalan efektif dan memberi hasil yang positif dalam meraih kinerja manajemen, karena adanya komitmen dari kelompok UKM atau industri kreatif dalam mengembangkan teknologi informasi untuk pengelolaan bisnisnya. Teknologi informasi bukanlah kebutuhan semata tetapi sudah menjadi bagian dari investasi jangka panjang yang dimanfaatkan mereka untuk mengelola usahanya sekaligus mengembangkan bisnisnya agar selalu mampu beradaptasi dengan perubahan yang bersifat dinamis. Pandemi covid-19 merupakan ajang bagi masyarakat UKMatauindustri kreatif untuk beradaptasi bisnis dengan teknologi informasi atau penggunaan aplikasi berbasis web, oleh karena itu implementasi program ePPMUKM memberikan pemahaman yang lebih komprehensif mengenai tata cara mengenali berbagai manfaat dan pengembangan teknologi informasi dan aplikasi berbasis web lainnya untuk pengelolaan bisnis di era industri 4.0. Mengedukasi masyarakat UKM atau industri kreatif merupakan program yang sangat sulit selama ini, berbagai keterbatasan sumberdaya sering dijadikan sebagai alasannya, namun pandemi covid19 telah merubah pola pikir dan menyadarkan mereka semua, bahwa untuk mewujudkan tatanan bisnis baru (new normal life) yang dapat diterima oleh masyarakat, maka bisnis harus dilakukan dengan pemanfaatan teknologi informasi atau aplikasi lainnya, walaupun setiap aplikasi memiliki kadar pemanfaatannya berbeda untuk setiap jenis usaha, sehingga persahabatannya dengan teknologi akan berjalan secara berkesinambungan selaras dengan tingkat perkembangan bisnis yang ingin dikembangkan hari ini dan masa yang akan datang, sehingga pengelolaan bisnis mampu menghadapi setiap perubahan yang mungkin terjadi agar pengalaman kegagalan usaha yang disebabkan oleh pandemi covid-19 tidak terulang kembali karena belum beradptasi dengan teknologi informasi atau aplikasi lainnya didalam mengelola usahanya.

Implementasi ePPM-UKM dan kinerja manajemen merupakan dua hal yang memiliki hubungan saling terkait, dimana kinerja manajemen akan menjadi semakin baik kalau masyarakat UKMatauindustri kreatif memiliki komitmen untuk menjadi bagian yang proaktif dalam implementasi program ePPM-UKM, karena akan terjadi proses transfer pengetahuan yang sangat masif untuk membantu pengembangan kemampuan manajemen yang mereka harapkan dapat memberi dukungan terhadap perubahan perilaku kreatif dan inovatif dalam memilih konsef dan fungsi manajemen serta pemilihan sumberdaya konseftual yang tepat dan berguna untuk mengelola bisnis secara efektif dan efisien. Demikian pula ePPM-UKM sebagai produk teknologi tepat guna, manakala diterapkan pada sekelompok UKMatauindustri kreatif secara terstruktur dan masif tentu akan memberi pengetahuan baru tentang manajemen melalui penawaran program pelatihan dan pendapingan manajemen, oleh karena itu implementasi program ePPMUKM baik secara langsung maupun secara tidak langsung memberikan kontribusi yang berarti bagi terciptanya kinerja manajemen menjadi lebih baik dibanding mereka yang tidak melakukan hal yang sama. Komitmen kelompok UKM atau industri kreatif yang ingin mengembangkan 
manajemennya, beradaptasi dengan perkembangan teknologi informasi dan aplikasi lainnya yang diterapkan untuk mengelola bisnisnya serta respon terhadap perubahan tentu akan memperkuat proses pengembangan kemampuan manajemennya secara berkesinambunganHasil temuan dalam penelitian ini adalah: (1) terdapat pengaruh langsung implemetasi ePPMUKM terhadap kinerja manajemen yang positip dan signifikan, (2) implementasi ePPM-UKM diperlukan untuk memperkuat kinerja manajemen, karena melalui kemampuan manajemen secara tidak langsung turut memberi pengaruh yang positif dan signifikan.

\section{Pengaruh Kemampuan Manajemen terhadap Kinerja Manajemen}

Kemampuan manajemen merupakan kepemilikan pengetahuan manajemen yang di butuhkan untuk menerapkan konsep dan fungsi manajemen dalam mengelola usahanya, dimana selama terjadi pandemi covid19 pengetahuan manajemen pelaku UKM dan industri kreatif tak mampu menghantarkan usaha mereka tetap eksis bahkan cenderung mengalami kemunduran, hal ini disebabkan oleh rendahnya daya nalar yang mengarah pada kreativitas dan inovasi manajemennya, bahkan tertinggalnya mereka dengan akses teknologi informasi yang di pergunakan untuk mengelola usahanya. Melalui peran sertanya dalam program implementasi ePPM-UKM pengetahuan manajemen mereka dapat ditingkatkan khususnya dalam mengikuti program pelatihan dan pendampingan yang dilakukan secara langsung maupun menggunakan aplikasi berbasis web. Transformasi pengetahuan manajemen yang diperoleh melalui ePPM-UKM menghantarkan mereka pada tingkat penguasaan manajemen yang mengarah pada perilaku kreatif dan inovatif dalam menerapkan fungsi manajemen untuk mengelola usahanya khususnya dalam memanfaat sumberdaya teknologi informasi, sehingga kelompok UKM dan industri kreatif yang telah mengikuti pro- gram ePPM-UKM menjadi lebih respon dengan perubahan, terus melakukan perbaikan proses manajemennya serta pemilihan sumberdaya ekonomi yang tepat. Kemampuan manajemen yang berorientasi pada teknologi informasi telah menghasilkan proses manajemen yang kreatif dan inovatif, sehingga memberi capaian pada kinerja manajemen yang lebih memadai seperti proses keputusan manajemen yang efektif, proses bisnis menjadi lancar, akses sumberdaya semakin luas, penggunaan sumberdaya semakin efisien, produk semakin inovatif dan biaya semakin efisien, oleh karena itu proses transformasi pengetahuan manajemen melalui program ePPMUKM sangat diperlukan agar kemampuan manajemen menjadi semakin kreatif dan inovatif, sehingga kinerja manajemennya menjadi lebih baik.

Kemampuan manajemen bukanlah suatu pengetahuan yang bersifat langka, tetapi suatu pengetahuan yang dapat dikembangkan melalui proses yang terstruktur dan sistematis baik secara formal maupun informal. Pembelajaran bisnis memberikan pengalaman sejati melalui proses waktu, dimana setiap pelaku bisnis akan memperoleh pengalaman secara langsung melalui interaksi dengan aktivitas bisnisnya, baik proses manajemen maupun proses bisnis lainnya. Kemampuan manajemen yang diperoleh melalui pembelajaran bisnis umumnya memerlukan waktu yang cukup lama dan kemampuan yang diperolehpun sangat terbatas pada apa yang dirasakan selama proses pembelajaran terjadi, namun hal ini sangat penting untuk pembentukan karakter sebagai entrepreneur sejati. Sedangkan kemampuan manajemen yang diperoleh melalui program ePPMUKM maupun program aplikasi lainnya umumnya lebih terstruktur dan sistematis, sehingga akan selaras dengan kebutuhan yang diinginkan oleh kelompok UKM atau industri kreatif, bahkan mereka dapat menentukan pengembangan kemampuan manajemen yang sesuai dengan pokok problem yang dihadapi selama ini, agar 
mereka dapat segera lepas dari kesulitan bisnis yang dialami sejak terjadi pandemi covid-19 enam bulan yang lalu. Transfer pengetahuan yang diperoleh melalui program ePPM-UKM sangat membantu mereka dalam pengenalan berbagai program aplikasi berbasis web atau pemahaman terhadap pemilihan sumberdaya konseftual (teknologi informasi) yang dapat dimanfaatkan untuk pengelolaan bisnis dan sumberdaya ekonominya lainnya.

Kemampuan manajemen akan terus berkembang, jika masyarakat UKM dan industri kreatif memiliki respon yang kuat terhadap perubahan, baik perubahan dalam berbisnis maupun perubahan terhadap perkembangan teknologi informasi yang akan dimanfaatkan untuk mengelola usahannya. Kemampuan manajemen yang sudah mengkristal akan tercermin dalam wujud perilaku kreatif dan inovatif dalam menghadapi perubahan lingkungnya. Oleh karena itu perubahan yang seringkali sulit untuk diprediksi, tetapi bagi pelaku usaha yang memiliki kemampuan manajemen yang mumpuni tentu akan mampu beradaptasi dengan perubahan, bahkan harus mampu menjadikan perubahan bukan sebagai hambatan tetapi justru sebagai peluang baru. Melalui perilaku kreatif dan inovatif tentu akan mentrasformasi perubahan tersebut menjadi produkataujasa inovatif, sehingga usaha mereka selalu hadir dihati konsumennya, tentu hal ini akan mendukung terwujudnya kinerja bisnis menjadi lebih baik. Proses perbaikan manajemen menjadi filosofi yang kuat untuk selalu memelihara dan menjaga kemampuan manajemennya agar tetap eksis dalam menghadapi setiap perubahan yang mungkin terjadi, oleh karena itu belajar beradaptasi dengan perkembangan teknologi informasi sangat membantu mereka untuk meng-update kemampuan manajemennya dari setiap perubahan, sehingga mereka tidak gagap lagi dengan hadirnya teknologi informasi, yang sebenarnya dapat membantu untuk mengelola sumberdaya dan bisnisnya, sehingga mereka selalu berada pada posisi yang siap berhadapan dengan perubahan apapun yang mungkin dapat menghambat usahanya.

Kemampuan manajemen juga tercermin pada kecermatan mereka untuk memilih suatu konsef dan menerapkan fungsi-fungsi manajemennya untuk mengelola seluruh sumberdaya ekonomi dan sumberdaya konseptual yang dimiliki saat ini atau yang mungkin dibutuhkan untuk pengembangan usahanya dimasa mendatang. Konsep dan fungsi manajemen selalu hadir ditengah proses bisnis, karena fungsi manajemen sendiri merupakan alat manajemen agar semua aktivitas usahanya dapat berproses dengan cara yang efektif dan efisien, oleh karena itu seluruh fungsi aspek manajemen harus mampu diarahkan untuk menghasilkan super value bagi konsumennya, sehingga kinerja manajemennya menjadi lebih baik, hal ini akan tercermin pada proses pengambilan keputusan yang efektif, proses bisnis berjalan lancar, akses sumberdaya ekonomi semakin luas, penggunaan sumberdaya semakin efisien, produk semakin inovatif dan biaya operasionalnya menjadi efisien. Kinerja manajemen yang baik tentu akan memberikan sumbangan yang positif bagi kinerja bisnisnya, oleh karena itu kemampuan manajemen harus terus dikembangkan selaras dengan kebutuhan bisnis dalam menghadapi kemungkinan terjadinya perubahan. Perilaku kreatif dan inovatif seharusnya diarahkan pada terciptanya aktivitas usaha yang selalu mengedepan ide-ide yang hidup di tengah bisnis mereka, sehingga setiap perubahan yang terjadi di tengah masyarakat bukan menjadi suatu tantangan tetapi justru menjadi suatu peluang yang sudah ditunggu melalui konsep inovatif dalam bisnis mereka. Kemampuan manajemen dan kinerja manajemen bukan dua hal berdiri sendiri, tetapi dua hal yang saling terkait satu dengan yang lainnya, oleh karena itu manakala kemampuan manajemen dapat dikembangkan dengan baik dan terus terpelihara kesinambungannya, maka kelom- 
pok UKMatauindustri kreatif akan memiliki kemampuan manajemen yang mumpuni untuk beradaptasi dengan perubahan yang terjadi, sehingga mereka mampu membangun kinerja manajemennya menjadi lebih baik. Kinerja manajemen yang baik tentu akan tercermin pada output yang lebih efektif, efisien dan inovatif terutama pada produk dan biaya opersionalnya. Hasil temuan dalam penelitian ini: (1) terdapat pengaruh langsung kemampuan manajemen terhadap kinerja manajemen yang positif dan signifikan, (2) kemampuan manajemen mampu menjadi mediasi pengaruh tidak langsung nilai implemtasi ePPM-UKM terhadap kinerja manajemen yang positif dan signifikan.

\section{SIMPULAN DAN SARAN Simpulan}

1. Implementasi ePPM-UKM berpengaruh langsung, positip dan signifikan terhadap kemampuan manajemen UKM dan industri kreatif. Hipotesis pertama yang menyatakan bahwa implementasi ePPM-UKM berpengaruh signifikan terhadap kemampuan manajemen UKM atau industri kreatif diterima. Program ePPM-UKM yang diimplementasikan secara terstruktur dan masif akan mendorong proses transformasi pengetahuan manajemen yang mengarah pada perubahan perilaku kreatif dan inovatif dalam mengelola usahanya, oleh karena itu program ePPM-UKM yang dimplementasikan secara terstruktur dan masif tentu akan meningkatkan kemampuan manajemen UKMatauindustri kreatif menjadi semakin kreatif dan inovatif dalam memilih konsef dan fungsi manajemen sehingga dapat memanfaatkan sumberdaya ekonomi dan sumberdaya konseptual secara efektif dan efisien.

2. Implementasi ePPM-UKM berpengaruh langsung, positip dan signifikan terhadap kinerja manajemen. Hipotesis kedua yang menyatakan bahwa implementasi ePPM-UKM berpengaruh signifikan terhadap kinerja manajemen di- terima. Program ePPM-UKM yang diimplementasikan secara terstruktur dan sistematis, akan mendorong proses transformasi sumberdaya konseftual yang mengarah pada kemampuannya untuk beradaptasi dengan perkembangan teknologi informasi dan aplikasi lainnya untuk mengelola usahanya, oleh karena itu program ePPM-UKM yang diimplementasikan secara terstruktur dan sistematis tentu akan meningkatkan kinerja manajemen UKM atau industri kreatif menjadi semakin efektif dan efisien dalam memilih investasi untuk pengembangan teknologi informasi yang selaras dengan kebutuhan untuk pengelolaan usahanya.

3. Kemampuan manajemen berpengaruh langsung, positip dan signifikan terhadap kinerja manajemen. Hipotesis ketiga yang menyatakan bahwa kemampuan manajemen berpengaruh signifikan terhadap kinerja manajemen diterima. Kemampuan manajemen yang dikembangkan secara terstruktur dan berkesinambungan akan meningkatkan proses pembelajaran bisnis semakin masif, melalui pemilihan konsep dan fungsi manajemen yang inovatif, beradaptasi dengan teknologi informasi yang aplikatif, oleh karena itu kemampuan manajemen yang dilakukan secara terstruktur dan berkesinambungan tentu akan memacu peningkatan kinerja manajemen UKM atau industri kreatif menjadi semakin efektif dan efisien dalam memilih sumberdaya konseftual yang dapat dimanfaatkan untuk proses manajemen dan pengelolaan usahanya.

\section{Implikasi}

Berdasarkan simpulan hasil penelitian, maka dapat dikemukakan implikasi hasil penelitian atau saran perbaikan sebagai berikut:

1. Implementasi ePPM-UKM merupakan program aplikasi berbasis web yang didesain dalam rangka mendukung 
pengembangan kemampuan manajemen UKM atau industri kreatif secara terstruktur dan masif, dimana melalui program aplikasi ini diharapkan akan terjadi proses transformasi pengetahuan yang sistematis dan berkesinambungan, sehingga mereka mampu memiliki pengetahuan yang memadai untuk dapat memilih konsep dan fungsi manajemen yang dapat dipergunakan untuk mengelola usahanya. Program ePPM-UKM telah mendesain paket program pelatihan dan program pendampingan yang dapat diikuti oleh kelompok UKM atau industri kreatif secara online, oleh karena itu melalui proses yang terstruktur dan berkesinambungan diharapkan pengembangan kemampuan manajemen akan berlangsung secara masif, sehingga mereka mampu beradaptasi dengan teknologi informasi maupun aplikasi lain yang dapat membantu untuk mengelola usahanya secara efektif dan efisien. Program pelatihan dan program pengembangan sebagai unsur utama di dalam ePPM-UKM merupakan desain aplikasi yang difokuskan untuk membantu kelompok UKMatauindustri kreatif yang mengalami kesulitan untuk mengembangkan usahanya selama pandemi covid-19, melalui implementasi program ePPM-UKM, diharapkan mereka dapat mengikuti program pengembangan kemampuan manajemen melalui aplikasi dari rumah saja, sambil tetap beraktivitas mengelola usahanya.

2. Kemampuan manajemen merupakan kepemilikan pengetahuan oleh kelompok UKM atau industri kreatif yang dapat diperoleh melalui proses pembelajaran bisnis atau melalui program yang terstruktur dan sistematis baik melalui pilihannya sendiri atau ePPM-UKM, melalui kemampuan manajemennya diharapkan mereka dapat menentukan pilihan untuk menerapkan konsep dan fungsi manajemen yang sesuai dengan kebutuhan bisnisnya, oleh karena itu kemampuan manajemen butuh pe- ngembangan secara berkesinambungan agar selalu mampu beradaptasi dengan setiap perubahan yang mungkin terjadi. Kemampuan manajemen yang layak akan tercermin pada perilaku kreatif dan inovatif dalam menghadapi perubahan, karena melalui pemanfatan teknologi informasi dan aplikasi yang tepat, tentu mereka mampu melakukan usaha yang inovatif sehingga mampu beradaptasi dengan setiap perubahan yang terjadi. Perubahan adalah sesuai yang pasti, tetapi kemampuan dalam menghadapi perubahan bukan hal yang pasti, oleh karena itu diperlukan sikap responsif agar tidak terlena saat perubahan hadir dihadapannya, jika memungkinkan perubahan itu harus dipandang sebagai peluang bisnis baru, untuk mendukung hal tersebut dibutuhkan kesiapan dalam memanfaatkan teknologi informasi dan aplikasi lain yang dapat memberi kemudahan dalam pengembangan dan mengelola usahanya, oleh karena itu kemampuan maanjemen yang mumpuni tentu akan menghasilkan proses manajemen yang efektif dan efisien, mendorong terwujudnya perilaku kreatif dan inovatif serta kemampuan beradaptasi dengan perkembangan teknologi informasi dan aplikasi lainnya yang sangat berguna untuk membantu menerapkan konsef dan fungsi manajemen didalam mengelola usahanya.

3. Kinerja Manajemen merupakan hasil akhir dari proses manajemen yang diterapkan oleh kelompok UKM atau industri kreatif melalui proses seleksi dan pemanfaatan sumberdaya ekonomi dan sumberdaya konseftual didalam mengelola usahanya. Kinerja manajemen sebagai hasil dari proses bukan ditentukan oleh kemampuan manajemen semata tetapi ada faktor lain yang turut mempengaruhinya, oleh karena itu sikap proaktif untuk mengikuti program ePPM-UKM secara terstruktur dan sistematis akan menuntun pada arah yang benar karena proses transfer 
pengetahuan akan terjadi secara masif. Kinerja manajemen bukanlah fokus bagi manajemen tetapi target yang diinginkan dapat terwujud, oleh karena itu fokus manajemen adalah bagaimana memiliki kemampuan manajemen yang mumpuni agar dapat mewujudkan target tersebut dengan baik, sedangkan langkah proaktif didalam program ePPM-UKM merupakan upaya memperoleh dan mengembangkan kemampuan manajemennya, agar mereka memiliki kemampuan memilih konsep dan menerapkan fungsi manajemen, memilih dan mengelola sumberdaya ekonomi dan sumberdaya konseptual yang efektif serta mampu beradaptasi dengan setiap perubahan yang mungkin terjadi, sehingga kinerja manajemen menjadi efektif demikian pula kinerja bisnis akan tercapai menjadi lebih baik dibanding mereka yang tidak melakukan hal yang sama. Sinkronisasi pengembangan kemampuan manajemen dan program ePPM-UKM harus dilakukan secara bijak, mengingat usahanya harus dapat bangkit kembali, namun disisi lain masih terdapat keterbatasan yang menyelimuti kondisi kelompok UKM atau industri kreatif yaitu keterbatasannya mengenali perkembangan teknologi informasi dan aplikasi lainnya, yang dapat dimanfaatkan untuk mengelola usahanya yang sempat berhenti sejenak karena terjadi pandemi covid-19 yang menimpa pada kelompok masyarakat UKM atau industri kreatif enam bulan lalu, yang dampaknya masih sangat terasa sampai saat sekarang, melalui program "UKM Indonesia Bangkit" diharapkan kelompok UKM atau industri kreatif di Indonesia dapat segera bangkit kembali dan berdampingan dengan perkembangan teknologi informasi serta aplikasi lainnya untuk diterapkan didalam mengelola bisnisnya.

\section{Keterbatasan Penelitian}

Simpulan dan implikasi tersebut di susun dengan mempertimbangkan adanya keterbatasan penelitian, agar hal ini dapat dijadikan pertimbangan dalam menelaah hasil yang lebih cermat sebagai berikut:

1. Penelitian ini dilakukan disaat pendemi covid-19 dimana kondisi psikologis para pelaku UKM atau industri kreatif sedang mengalami krisis kepercayaan diri, dengan mengikuti program ePPM-UKM dalam waktu yang singkat, proses transformasi pengetahuan belum berjalan secara optimal, tentu akan berbeda hasilnya jika penelitian ini dilakukan setelah satu tahun, karena manajemen akan mengalami proses pembelajaran dengan waktu yang memadai sehingga dampaknya lebih terstruktur dan masif.

2. Penelitian ini tidak membedakan skala usaha dan lama pengalaman mereka sebagai pelaku usaha, dimana pengalaman bisnis selama ini tentu mempengaruhi kemampuan manajemen dan kinerja usahanya, sedangkan fokus dalam penelitian ini adalah dampak dari implementasi program ePPM-UKM bagi pelaku UKM atau industri kreatif agar dapat memperoleh pengetahuan manajemen berbasis teknologi informasi.

3. Penelitian ini tidak mengkaji aspek sumberdaya manusia, orientasi kewirausahaan, akses pasar, orientasi pemasaran, kondisi makro dan daya beli konsumen, dimana aspek ini tentu ada pengaruhnya secara tidak langsung terhadap kemampuan manajemen maupun kinerja manajemen pada pelaku UKM atau industri kreatif

\section{DAFTAR PUSTAKA}

Ahmadi, M., dan Mohd. Osman, M. H. 2018. How can small and medium-sized enterprises maximize the benefit derived from Strategic flexibility? The moderating effect of Contextual Ambidextrous Learning. Indian Journal of Science and Technology. https:atauataudoi.orgatau10.17485atauij statau2018atauv11i11atau118692

Chang, A. Y., dan Cheng, Y. T. 2019. Analysis model of the sustainability 
development of manufacturing small and mediumsized enterprises in Taiwan. Journal of Cleaner Production. https:atauataudoi.orgatau10.1016atauj.j clepro.2018.10.025

Choi, J. K., Thangamani, D., dan Kissock, K. 2019. A systematic methodology for improving resource efficiency in small and medium-sized enterprises. Resources, Conservation and Recycling. https:atauataudoi.orgatau10.1016atauj.r esconrec.2019.04.015

Dolz, C., Iborra, M., dan Safón, V. 2019. Improving the likelihood of SME survival during financial and economic crises: The importance of TMTs and family ownership for ambidexterity. $B R Q$ Business Research Quarterly. https:atauataudoi.orgatau10.1016atauj.b rq.2018.09.004

Falahat, M., Ramayah, T., Soto-Acosta, P., dan Lee, Y. Y. 2020. SMEs internationalization: The role of product innovation, market intelligence, pricing and marketing communication capabilities as drivers of SMEs' international performance. Technological Forecasting and Social Change.

https:atauataudoi.orgatau10.1016atauj.t echfore.2020.119908

Felício, J. A., Caldeirinha, V., dan Dutra, A. 2019. Ambidextrous capacity in small and medium-sized enterprises. Journal of Business Research, 101, 607-614. https:atauataudoi.orgatau10.1016atauj.j busres.2019.02.061

Fitriati, T. K., Purwana, D., dan Buchdadi, A. D. 2020. The role of innovation in improving small medium enterprise (SME) performance. International Journal of Innovation, Creativity and Change 11(2): 232-250.

Goerzig, D., dan Bauernhansl, T. 2018. Enterprise Architectures for the Digital Transformation in Small and Mediumsized Enterprises. Procedia CIRP. https:atauataudoi.orgatau10.1016atauj.p rocir.2017.12.257

Hassan, N., dan Raziq, A. 2019. Effects of knowledge management practices on innovation in SMEs. Management Science Letters 9(7): 997-1008.

https:atauataudoi.orgatau10.5267atauj. msl.2019.4.005

Henriques, J., dan Catarino, J. 2016. Motivating towards energy efficiency in small and medium enterprises. Journal of Cleaner Production.

https:atauataudoi.orgatau10.1016atauj.j clepro.2016.08.026

Hervas-Oliver, J. L., Sempere-Ripoll, F., Boronat-Moll, C., dan Estelles-Miguel, S. 2020. SME open innovation for process development: Understanding process-dedicated external knowledge sourcing. Journal of Small Business Management 582: 409-445.

https:atauataudoi.orgatau10.1080atau00 472778.2019.1680072

Janasová, D., Bobáňová, V., dan Strelcová, S. 2017. Networking of Small and Medium Enterprises into Clusters in the Slovak Republic. Procedia Engineering. https:atauataudoi.orgatau10.1016atauj.p roeng.2017.06.064

Lin, F. J., dan Ho, C. W. 2019. The knowledge of entry mode decision for small and medium enterprises. Journal of Innovation and Knowledge. https:atauataudoi.orgatau10.1016atauj.ji k.2018.02.001

Maarof, M. G., dan Mahmud, F. 2016. A Review of Contributing Factors and Challenges in Implementing Kaizen in Small and Medium Enterprises. Procedia Economics and Finance.

https:atauataudoi.orgatau10.1016ataus2 212-5671(16)00065-4

Mulolli, E., Islami, X., dan Skenderi, N. 2017. Business Incubators as a Factor for the Development of SMEs in Kosovo. International Journal of Management, Accounting and Economics International Journal of Management, Accounting and Economics International Journal of Management, Accounting and Economics.

Okundaye, K., Fan, S. K., dan Dwyer, R. J. 2019. Impact of information and 
communication technology in Nigerian small-to medium-sized enterprises. Journal of Economics, Finance and Administrative Science 24(47): 29-46. https:atauataudoi.orgatau10.1108atauJE FAS-08-2018-0086

Ombi, N., Ambad, S. N. A., dan Bujang, I. 2018. The Effect of Business Development Services on Small Medium Enterprises (SMEs) Performance. International Journal of Academic Research in Business and Social Sciences 8(3). https:atauataudoi.orgatau10.6007atauija rbssatauv8-i3atau3910

Prashar, A. 2019. Towards sustainable development in industrial small and
Medium-sized Enterprises: An energy sustainability approach. Journal of Cleaner Production. https:atauataudoi.orgatau10.1016atauj.j clepro.2019.07.045

Sawaean, F. A. A., dan Ali, K. A. M. 2020. The impact of entrepreneurial leadership and learning orientation on organizational performance of SMEs: The mediating role of innovation capacity. Management Science Letters 10(2): 369-380.

https:atauataudoi.orgatau10.5267atauj. msl.2019.8.033 